\title{
Facilities connectivity in eastern regions of China and Russia and the "Belt and Road" initiative
}

\author{
X. Zhang \\ Northeast Asian Studies, Heilongjiang Provincial Academy of Social Sciences, Harbin, China; \\ e-mail: zhangxiujie203@163.com
}

\begin{abstract}
Enhancement of facilities connectivity and construction of the necessary infrastructure is an important element of the "Belt and Road" Initiative. The lack of facilities connectivity is seen as a major impediment to the development of Sino-Russian trade and other spheres of cooperation between the two countries. This paper provides an overview of the current approaches to the concept of facilities connectivity in the context of Sino-Russian cooperation within the framework of the "Belt and Road" initiative. The author examines the progress in the construction of transport infrastructure aimed at improving the facilities connectivity in China's and Russia's eastern regions over the past five years. A specific focus is made on such large-scale projects as the construction of China-Mongolia-Russia economic corridor, the construction of bridges (for example, Tongjiang Railway Bridge and Heilongjiang Bridge), the construction of the Harbin-Russia International Freight Line and so on. The case of Heilongjiang Province in China is described in the article to illustrate the benefits of the "Belt and Road" initiative for regions along the border of China and Russia. Greater facilities connectivity and establishment of cross-border economic cooperation zones are expected to enhance the economic prosperity of these regions. The author proposes recommendations regarding further development of the railway and other transport connections between Russia and China and shows how these improvements could help both countries to efficiently meet the goals of the "Belt and Road" initiative and achieve mutually beneficial results.
\end{abstract}

\section{KEYWORDS}

China, Russia, Far East, Belt and Road, facilities connectivity

\section{FOR CITATION}

Zhang X. (2019) Facilities connectivity in eastern regions of China and Russia and the "Belt and Road" initiative. R-economy, 5(3), 144-150. doi: 10.15826/recon.2019.5.3.015

\section{Транспортная инфраструктура в восточных регионах Китая и России и инициатива «Один пояс, один путь»}

\section{С. Чжан}

Институт североазиатских исследований, Академия соииальньх наук провиниии Хэйлунизян, Харбин, Kumaü; e-mail: zhangxiujie203@163.com

\section{АННОТАЦИЯ}

Расширение возможностей соединения объектов и создание необходимой инфраструктуры является важным элементом инициативы «Один пояс, один путь». Отсутствие связи между объектами рассматривается как серьезное препятствие на пути развития китайско-российской торговли и других сфер сотрудничества между двумя странами. В данной статье дается обзор современных подходов к концепции соединения объектов в контексте китайско-российского сотрудничества в рамках инициативы «Один пояс, один путь». Автор рассматривает прогресс в строительстве транспортной инфраструктуры, направленной на улучшение связности объектов в восточных регионах Китая и России за последние пять лет. Особое внимание уделяется таким масштабным проектам, как строительство экономического коридора Китай-Монголия-Россия, строительство мостов (например, железнодорожного моста Тунцзян и моста Хэйлунцзян), строительство международной грузовой линии Харбин-Россия и пр. Пример провинции Хэйлунцзян в Китае описан в статье, чтобы проиллюстрировать преимущества инициативы «Один пояс, один путь» для пограничных регионов Китая и России. Ожидается, что расширение возможностей соединения объектов и создание трансграничных зон экономического сотрудничества повысят экономическое процветание этих регионов. Автор предлагает рекомендации по дальнейшему развитию железнодорожного и других транспортных связей между Россией и Китаем и показывает, как эти улучшения могут помочь обеим странам достичь взаимовыгодных результатов. ๑) X. Zhang, 2019

\section{КЛЮЧЕВЫЕ СЛОВА}

Китай, Россия, Дальний Восток, Пояс и Дорога, связность объектов

\section{ДЛЯ ЦИТИРОВАНИЯ} Zhang X. (2019) Facilities connectivity in eastern regions of China and Russia and the "belt and road" initiative. R-economy, 5(3), 144-150. doi: 10.15826/recon.2019.5.3.015 


\section{Introduction}

Connectivity of the facilities within the "Belt and Road" initiative plays a key role in the success of this project. Good infrastructure is a prerequisite for the development of a country or region; connectivity of infrastructure networks, in its turn, is crucial for economic cooperation and technological exchange, it is also one of the factors that determine the economic and trade cooperation between Russia and China. The construction of cross-border transportation infrastructure between China and Russia has recently made some major breakthroughs, but the interconnection between transportation trunk lines and modernization construction has yet to be improved. Once the construction of the interconnectivity infrastructure is finished, the freight routes from Eastern Russia to the northern provinces of China will become shorter, which, in its turn, will cut the costs of shipping Chinese goods to Russia and enhance the trade between the two countries. Moreover, it will also stimulate economic development of Northeast China, which serves as a bridge in China-Russia trade.

The majority of up-to-date Chinese studies discuss the significance of facilities connectivity and provide interpretations for the concept of facilities connectivity and the relevant policies in this sphere. In this article we are going to focus on the construction of cross-border transportation infrastructure and describe the possible means and ways for enhancing the connectivity of facilities within the "Belt and Road" project and for harmonizing Russian and Chinese respective development strategies.

\section{Literature review}

The "Vision and Actions on Jointly Building Silk Road Economic Belt and 21 $1^{\text {st }}$-Century Maritime Silk Road" issued by the Chinese government states ${ }^{1}$ that facilities connectivity is the priority area of the "Belt and Road" Initiative. The project aims to stimulate the construction of traffic facilities in the countries participating in the project, especially the construction of the missing sections and links. Regarding the concept of facilities connectivity, we can identify three categories of studies in China.

The first group of studies deals with the concept of facilities connectivity. Liu Xu and Chen Yao [1] define this term as construction of trans-

http://en.ndrc.gov.cn/newsrelease/201503/ t20150330 669367.html portation, communications, networks, ports, and other kinds of infrastructure. The general understanding is that the "Belt and Road" initiative seeks to enhance the interconnection of transportation, energy and communications, especially regarding large passageways [2].

According to the "Report of the Five-Pronged Approach Index of the Countries along the Belt and Road" published by the research group of Peking University ${ }^{2}$, the connectivity of transport infrastructure should be provided through cooperation among the participant countries. At the same time, these countries' sovereignty and security concerns should be respected and taken into consideration. Border countries should coordinate their efforts in infrastructure construction planning and harmonize their technical guidelines and systems. The first problem to be addressed is that of "disconnection and impassability": the countries are expected to build the missing sections, set up an international three-dimensional transport corridor and build the infrastructure network linking Asian sub-regions and Asia, Europe and Africa.

The second group of studies deal with the significance of facilities connectivity. Li Jinzao, Tang Min, Li Ruogu and other scholars see the construction of transport infrastructure within the "Belt and Road" Initiative as the key condition for enhancing regional economic integration [3]. Infrastructure is crucial for the success of the project, roads and communications should be opened in the first place, it is necessary to build an efficient, convenient and safe infrastructure network [4]. The interconnected infrastructure built in compliance with the standards is the basic condition for the development of trade, capital allocation, personnel flow and industrial cooperation. As the global experience shows, regional economic cooperation is heavily dependent on the quality of the infrastructure, in particular its connectivity. Many countries attach great importance to infrastructure construction and enhancement of connectivity. For instance, regional economic organizations, such as the European Union and ASEAN, have implemented special policies and plans to improve their facilities connectivity [5].

Building infrastructure is particularly important as it provides the basis for unimpeded trade

2 Peking University. (2016). "Belt and Road" FivePronged Index Research Group: National Five-Pronged Pronged Pronged Index Report along the "Belt and Road". The economic daily press, 11,36 
and, therefore, affects economic development and living standards in the region [6]. Participation in the "the Belt and Road" facility construction will help the countries maximize their respective advantages and achieve mutual benefit and win-win results [7].

Improved transport interconnection can accelerate China's economic development, ensure balanced development of regional economy, promote economic and trade exchange, and contribute to the economic development of other participants of the "Belt and Road" project.

A separate group of studies present a Russian perspective on the "Belt and Road" project. For example, Ostrovsky stresses that the rapid development of the Russian Far East requires the implementation of large-scale infrastructure projects, which makes China Russia's best partner in this respect. Russia can benefit from the opportunities to develop its transportation infrastructure in the Far East and Eastern Siberia by participating in the construction of the China-Mongolia-Russia Economic Corridor [8]. Suslov believes that the cooperation between Russia and China in the implementation of the International Transportation Corridor project will improve cargo transportation from provinces of Northeast China through the ports of Primorsky region and help to solve the development problems in Russia's Far East and Northeast China [9].

The third category of studies focus on what is referred to as the "structural adjustment" of facilities connectivity: Han Kedi and Wang Zhiyuan believe that the countries along "the Belt and Road" have a great potential for complementary development [10]. From the perspective of Sino-Russian cooperation, facilities connectivity mainly refers to three aspects: cross-border water transportation, transportation, and customs clearance at ports. As for cross-border water transportation, over the years, China has been quite active in bridging the border areas between China and Russia, and there has been some progress in the construction of Tongjiang and Heilongjiang Bridges. In terms of transportation, China and Russia have basically reached consensus on expanding transport in Eurasia and strengthening cooperation with countries along the Silk Road Economic Belt. In recent years, the opening of the Siberian Land Bridge, and the launch of "Madrid-Yiwu Train", "Chongqing-Sinkiang-Europe International Railway", "Harbin-Europe International Rail- way" and "Harbin-Russia International Railway" have marked important stages in promoting the development of trade between the two countries. In terms of port customs clearance, for the construction of the "Silk Road Economic Belt", it is necessary to solve the problem of the bottleneck of port infrastructure [10]. This can be achieved with the help of free trade zones around the key port areas and by improving the efficiency in the logistics sector.

There is still a lot of room for exploring the opportunities for enhancing facilities connectivity both for China and Russia, but special attention should be given to the existing structural problems. For efficient implementation of the project it is necessary to consider resource allocation and mobilize effectively the governments, enterprises and other stakeholders [11].

\section{Expected Goals of China-Russia Facilities Connectivity}

Since the "Belt and Road" initiative was put forward, China and Russia have launched a number of major construction projects. In this article, we are going to look at the progress of building the Tongjiang Railway Bridge and Heilongjiang Bridge in Heihe, which reflects the efforts of both countries to improve facilities connectivity. We are also going to analyze the significance of strategic cooperation between the two countries.

Russia's Far East is adjacent to Northeast China, which means that Russia's development of the Far East is beneficial for Northeast China. In 2004, China made a major decision to implement the strategy of revitalizing the old industrial bases in Northeast China. In 2016, the State Council put forward a new round of plans for the revitalization of this region. In September 2019, President $\mathrm{Xi}$ Jinping visited three northeastern provinces and hosted a symposium on promoting the revitalization of Northeast China, where he spoke of a series of decision-making arrangements of the Party Central Committee.

It should be noted that the local revitalization strategies of Russia and China have a lot in common and have significant potential for strategic synergy. During the 4th Russian Eastern Economic Forum, the Sino-Russian Dialogue of Local Leaders briefed on the progress of construction of infrastructure projects such as bridges and highways, showing the success of Sino-Russian cooperation in the eastern region. 
In 2017, the government of Heilongjiang Province proposed ${ }^{3}$ the following goals for the "Belt and Road" construction: "making a window (an important window for China's opening to the North) and building four zones (Heilongjiang (China-Russia) Free Trade Area, key open pilot areas along the border, demonstration zones for cross-border economic cooperation and Eurasian logistics hub areas)". These goals include construction of the Eurasian logistics hub area, which also means enhancing the collection and distribution system, promotion of cross-border infrastructure interconnection, building international economic and trade corridors, creating professional logistics parks, logistics groups and logistics enterprises, as well as modern intelligent logistics industrial clusters ${ }^{4}$. As an open window to the north, Heilongjiang Province is not only shouldering the heavy responsibility of ensuring facilities interconnectivity between China and Russia, but is actually taking the lead in this process.

In June 2017, Heilongjiang Provincial Government adopted the Thirteenth Five-Year Plan for the Development of the Modern Integrated Transport System, which proposed to strengthen the province's cooperation with Russia in the sphere of cross-border infrastructure construction. It was also planned to upgrade the functions of the "Harbin-Russia-Europe" corridor and the "Harbin-Russia-Japan-Korea" land-sea joint transport channels, to open new international road transport lines, to construct a large land-seaair Silk Road corridor and China-Mongolia-Russia economic corridor ${ }^{5}$. Let us look at these plans in more detail.

\section{China-Mongolia-Russia economic corridor}

The concept of China-Mongolia-Russia economic corridor expands and complements the idea behind the "Belt and Road" initiative. The

\footnotetext{
3 The Provincial Party Committee Convened the First Meeting of the Provincial Leading Group on "the Belt and Road" Construction (2017). Heilongjiang Development and Reform Commission. Retrieved from: http://www.hljdpc.gov.cn/ art/2017/8/18/art 350 19546.html

${ }^{4}$ The Provincial Party Committee Convened the First Meeting of the Provincial Leading Group on "the Belt and Road" Construction (2017). Heilongjiang Development and Reform Commission. Retrieved from: http://www.hljdpc.gov.cn/ art/2017/8/18/art 350 19546.html

5 The $13^{\text {th }}$ Five-Year Plan for the Development of Modern Comprehensive Transportation System in Heilongjiang Province (2017). Heilongjiang Provincial Government Information Disclosure. Retrieved from: http://www.chinahighway.com/ news/2017/1113184.php
}

purpose of building this corridor is to gradually improve the interconnection between these countries, thus enhancing their economic cooperation and economic development. Better connectivity means addressing the problem of transport bottlenecks and turning the struggling border areas into prosperous cross-border economic zones. This is true in particular for Heilongjiang Province, which has the potential to become the core part of the corridor [12].

The 12th Party Representatives Congress of Heilongjiang Province declared the intention of the Province's government to "focus on optimizing the pattern of opening up to the outside world", which includes "focusing on cooperation with Russia, and promoting cooperation with Europe, the United States, Northeast Asia, Central Asia, Australia, New Zealand, Mongolia and other countries and regions, working closely with Hong Kong, Macao and Taiwan, and deepening economic and trade cooperation and human exchanges" [13].

Heilongjiang is an important hub and the main channel between China and the rest of Eurasia. The province has the potential to become a major regional center for international cooperation. This will be made possible by the construction of a cross-border railway transport system between China, Russia and Europe, the supporting infrastructure, and the Eurasian Continental Bridge. Other priority areas include land-sea transportation, river-sea transportation, Suifenhe-Manzhouli Expressway, Harbin Airport Economic Zone, Japan Sea Route, Arctic Route and other cross-border channels.

\section{Projects to enhance highway and railroad connectivity}

The "Vision and Actions on Jointly Building the Silk Road Economic Belt and 21 $1^{\text {st }}$ Century Maritime Silk Road" highlights 18 key provinces, including Heilongjiang Province, and describes the main priorities of international cooperation. Among other things, it is planned to improve Heilongjiang's railway access to Russia and its regional railway network. Yet another area outlined by the document deals with strengthening of landocean cooperation between the province and Russia’s Far East ${ }^{6}$.

${ }^{6}$ Visions and Actions of Promoting the Construction of the Silk Road Economic Belt and the Marine Silk Road in the 21 $1^{\text {st }}$ Century (2017). Retrieved from: http://ydyl.people.com.cn/ n1/2017/0425/c411837-29235511.html 
So far the government of Heilongjiang Province has gone to great lengths to accelerate the construction of railway links along the Russian border, to build high-speed railway loops, railway ports links, key highway networks and civil aviation airports. In this respect, it is important to mention such significant projects as the building of Tongjiang Railway Bridge, China-Russia Heihe Highway Bridge, Dongning Cross-Border Highway Bridge, Heixiazi Island Land Port, and the construction and management of Vladivostok Port. All these projects will make a considerable contribution to the cooperation between Russia and China.

After the project of constructing Tongjiang Railway Bridge is officially completed, Tongjiang Port will be connected with the Trans-Siberian Railway, linking Khabarovsk, one of the largest cities in the Far East, and Europe. It is expected that 20 million tons of cargo will be transported via the bridge in the future [14].

Heihe Highway Bridge, connecting Heihe in Heilongjiang province and Blagoveshchensk in Russia, will be the first modern highway bridge on the Amur River. After its completion, a new international highway will provide a direct connection between the two cities of China and Russia, playing an important role in promoting Sino-Russian trade.

The transnational transportation system (mainly railway freight trains) in Heilongjiang Province currently comprises trains running from Harbin to Europe and to Russia as well as the land-sea transport line "Harbin-Suifenhe-Vladivostok-Busan". Since its opening in June 2015, the volume of the rail traffic between Harbin and Europe has been increasing continuously. According to the statistics, the full loading rate has increased from $21.34 \%$ to $49.6 \%$.

On May 13, 2017, Heilongjiang-Belgium Volvo special line project was launched. Then the line Harbin-Minsk was opened, which is the first central European line to reach Minsk directly. Harbin-Russia international freight line, opened in February 2016, is now operating on a regular basis and has been playing an important role in freight transportation between China and Russia. It now takes 7-10 days to ship a container with cargo from China to Russia or in the opposite direction.

On January 5, 2017, Harbin-Europe and Harbin-Russia railway lines were formally incorporated into the Central European Trains Oper- ation Map. These railway lines link China with Europe, playing a key part in the development of cross-border e-commerce and other related spheres. The development of railway transportation holds massive potential for the development of Heilongjiang province [15].

In August 2015, the first land-sea container train with Chinese goods departed from Harbin, heading all the way to Vladivostok, and then to Busan by sea. A transport line from Harbin, Vladivostok to Busan was opened. After nearly a year of trial operation, in April 2016, this line started its normal operation. It takes two days for a train to reach The implementation of the projects aimed at creating China-Mongolia-Russia economic corridor, the international transport corridor between Vladivostok and Harbin "Binhai No. 1", and the land-sea transport line "Harbin-Suifenhe-Vladivostok-Busan" has been a great contribution to building a reliable and efficient transportation system in Russia's Far East and Heilongjiang province.

\section{The Future of China-Russia Cooperation for the Improvement of Facilities Connectivity}

In recent years, Russia has been severely affected by Western sanctions and the global financial crisis. As a result, the state investment in fixed assets became inadequate, which seriously impeded the construction of the necessary transport infrastructure. The authorities of Russia's Far East attach great importance to attracting foreign investment to building the infrastructure, which provides opportunities for China-Russia cooperation in this sphere. China-Russia infrastructure construction should meet the needs of both countries resulting in a win-win situation and be implemented step by step; government and enterprises should play a synergistic role in improving the utilization rate of infrastructure, focusing on solving the problems of high risk and poor profitability.

There are several aspects that need to be considered when thinking about the future China-Russian cooperation in the sphere of facilities connectivity and construction of the necessary transport infrastructure.

First, one cannot overestimate the significance of China-Mongolia-Russia economic corridor. The key directions of China-Russia cooperation in this area are to jointly plan and develop infrastructure resources such as tripartite roads, 
railways, airports and sea ports, strengthen cooperation in establishing international transport corridors, border infrastructure and cross-border transport organizations. China-Mongolia-Russia economic corridor will also provide the necessary support for Manzhouli-Suifenhe railway, which connects with the Northeast China Railway Network in the south and extends to North China. It is also linked to the Russian Trans-Siberian Railway in the north and extends to the Russian Far East through the Baikal-Amur Railway. Thus, it is a core railway line in Northeast Asia.

Second, the Russian socio-economic advanced development zone in the Far East is one more step towards the creation of the modern transportation infrastructure on the route between China and Russia, which enable both countries to efficiently transport such resources as oil, natural gas, timber and coal. At present, the Russian government has already approved the establishment of ten advanced development zones with preferential tax policies across the Far East. It should be noted that this region is now suffering from a serious shortage of investment. This problem could be addressed through joint efforts of the two countries, which could include funding from the Asian Investment Bank and the Silk Road Fund to invest in the key projects of the Russian Far East [16].

Third, one must be fully aware of the significance of mutual trust between the countries. In order to expand cooperation and partnership, it is necessary to strengthen friendly ties between the people, which will thus provide a solid social foundation for realizing the "Belt and Road" project. In terms of facilities connectivity, it is necessary to balance the interests of both countries, improve the internationalization norms and transparency within the project, and avoid or reduce the differences caused by misjudgments. Mutual trust and cooperation should be strengthened in line with the concepts of coordinated development and green development [17].

\section{Conclusion}

At present, the initial stage of enhancing the facilities connectivity within the "Belt and Road" project has been already completed, although many routes and plans are still a work in progress. A certain success was achieved in the eastern area, where China and Russia have joined their efforts.

In this paper, we explored the ways of improving facilities connectivity in the east, in particular in Heilongjiang Province. We conducted some field research, especially regarding cross-border water transport and land-sea transport, which allowed us to fill the existing research gap.

On the other hand, since facilities connectivity of the "Belt and Road" is a relatively new idea, there is still much room for improvement. The success of the project depends on the successful of specific projects such as the construction of China-Mongolia-Russia economic corridor and the establishment of a socio-economic advanced development zone in Russia's Far East. The process is also influenced by the economic situation in China and in Russia.

In 2019 , the $70^{\text {th }}$ anniversary of China-Russia diplomatic relations was celebrated. The comprehensive strategic partnership between the two countries encompasses a wide range of spheres, including trade and transportation. It is expected that by 2024 , the volume of Sino-Russian trade will reach US $\$ 200$ billion, which makes one quite optimistic about the future of this mutually beneficial relationship.

\section{References}

1. Zhang Jingwen (2017). Research Summary of the Belt and Road Facilities Connectivity. Co-operative Economy \& Science, 12, 50. (In Chinese)

2. Jing An (2014, December 23). Promoting the Belt and Road to Implementation Comprehensively Next Year. China Trade News. pp. A1. (In Chinese)

3. Li Ruogu (2015, June 17). The Belt and Road Leading Global Investment Trend. $21^{\text {st }}$ Centery Business Herald. Pp. A16. (In Chinese)

4. Li Jinzao (2014). Promoting the Belt and Road: Making a Thorough Study of the Thought of President Xi Jinping on the Belt and Road. Finance and Accounting for International Commerce, $8,5-7$. (In Chinese)

5. Ren Weimin (2017). Facilities Connectivity: Foundation of Cooperative Development of the Belt and Road. QStheory, 11, 5. (In Chinese)

6. Zheng Yating (2017). "One Belt And One Road" along the national infrastructure connectivity facing difficulties and countermeasures. Contemporary Economics, 23, 8. (In Chinese) 
7. Luo Yuze (2017). Thoughts and Policies of Promoting the Belt and Road Facilities Connectivity. Journal of Chongqing University of Technology, 7, 1-5. (In Chinese)

8. Ostrovsky, A. (2019, June). Take advantage of the "Belt and Road Initiative" to seize new opportunities for future China-Russian cooperation. In: Paper presented at the Proceedings of the 6th China-Russia Economic Cooperation High-level Think Tank Forum, Harbin (pp. 8).

9. Suslov, D. (2019, June). The status quo and prospects of cooperation between Russia and China in the Far East. In: Paper presented at the Proceedings of the $6^{\text {th }}$ China-Russia Economic Cooperation High-level Think Tank Forum, Harbin (pp. 225).

10. Han Kedi, \& Wang Zhiyuan (2015). Deep Thoughts on Sino-Russian Cooperation and Risk Prevention from the Perspective of "the Silk Road Economic Belt". Academic Journal of Russian Studies, 5, 61-67. (In Chinese)

11. Sun Qi (2016). Attention should be paid to "structural adjustment" in the "facility connection" between China and Russia. Academic exchanges, 2, 221. (In Chinese)

12. Qu Jing (2016). Expanding International Friendship Circle and Opening up Heilongjiang. Heilongjiang New. Retrieved from: http://epaper.hljnews.cn/hljrb/20160219/179003.html (In Chinese)

13. Zhang Qingwei (2017). Closely Unite around the Party Central Committee with President Xi Jinping and Strive to Opening up New Routes of Comprehensive Revitalization and Development of Heilongjiang Province. CPC News, Retrieved from: http://cpc.people.com.cn/n1/2017/0508/c6410229260713.html (In Chinese)

14. Zhang Aqiang (2017). Heilongjiang Shows "the Belt and Road" Three Years Report Card. China City News, 5, 12-14. (In Chinese)

15. Wu Wenhua, \& Fan Yijiang (2017). One Belt And One Road infrastructure connectivity has yielded fruitful results. Money China, 2, 26-27. (In Chinese)

16. Liu Shuang, \& Ma Youjun (2017). Investigation and Analysis of Infrastructure Construction in China-Russian Border Areas. Russian Central Asian \& East European Market, 1, 72. (In Chinese)

17. Yu Hongjun (2018). Facilities Unicom: A realistic path to integrate development and common prosperity. Northern Economy, 11, 4. (In Chinese)

\section{Information about the author}

Xiujie Zhang - Researcher of Institute of Northeast Asian Studies, Heilongjiang Provincial Academy of Social Sciences (No. 1000 Shibo Road, Songbei District, 150028, Harbin, China); e-mail: zhangxiujie203@163.com

ARTICLE INFO: received April 8, 2019; accepted June 28, 2019

\section{Информация об авторе}

Чжан Сюцзе - исследователь, Институт североазиатских исследований, Академия социальных наук провинции Хэйлунцзян (150028, Китай, Харбин, Сунбей Дистрикт, Шибо Род, No. 1000); e-mail: zhangxiujie203@163.com

ИНФОРМАЦИЯ О СТАТЬЕ: дата поступления 8 апреля 2019 г.; дата принятия к печати 28 июня 2019 г.

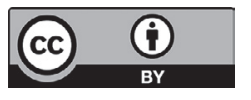

This work is licensed under a Creative Commons Attribution 4.0 International License

Эта работа лицензируется в соответствии с Creative Commons Attribution 4.0 International License 